\title{
A léces martenzit összetett jellegének vizsgálata
}

\section{Investigation of composite behaviour of lath martensite}

\author{
Maróti János Endre, ${ }^{1}$ Szabó Péter János ${ }^{2}$ \\ Budapesti Müszaki és Gazdaságtudományi Egyetem, Gépészmérnöki Kar, Anyagtudomány és Technológia \\ Tanszék, Budapest, Magyarország \\ ${ }^{1}$ maroti@eik.bme.hu \\ ${ }^{2}$ szpj@eik.bme.hu
}

\begin{abstract}
It is very important for our research that we are able to examine the orientation of packets and their relationship to directions of stress that cause plastic deformation. We use electron backscatter diffraction (EBSD) to achieve this. EBSD examination requires very careful sample preparation. In our work we have developed a sample preparation method for electron backscatter diffraction examination. In this study we present the method, which consists of multistage mechanical grinding, polishing and ion polishing. Optimal parameters for each steps (eg.: grinding, polishing and sputtering time, milling angle) were determined for lath martensitic microstructured steel, however, it could be used for other type of steel with minor adjustments.
\end{abstract}

Keywords: austenite, martensite, EBSD, sample preparation.

\section{Összefoglalás}

Kutatásunk szempontjából nagyon fontos, hogy meg tudjuk vizsgálni a kötegek orientációját és ennek viszonyát az alakváltozást okozó feszültség irányával. Ehhez úgynevezett visszaszórtelektron-diffrakciós vizsgálatot (EBSD) alkalmazunk. Ennek a vizsgálatnak az elvégzése nagyon gondos minta-előkészítést igényel. A tanulmányban az általunk kidolgozott módszert mutatjuk be, amely többlépcsős mechanikai csiszolásból, polírozásból, valamint ionpolírozásból áll. Az egyes lépések optimális paramétereit (pl: mechanikai csiszolás, polírozás, ionpolírozás ideje, minta ionpolírozás közbeni dőlésszöge) a léces martenzites szövetszerkezetű acél mintákra határoztuk meg, amelyek kis módosításokkal más szövetszerkezetű acél próbatesteknél is alkalmazhatóak.

Kulcsszavak: ausztenit, martenzit, EBSD, minta-előkészítés.

\section{Bevezetés}

A martenzites acélok az egyik legszélesebb körben használt vasalapú szerkezeti anyagok, nagyon kedvező mechanikai tulajdonságokkal. A martenzites szövetszerkezetű acélok egyik fő ötvözője a szén (C), amely tömegrészaránya $10^{-2}$ százaléktól 0,8 százalékig terjed, továbbá tartalmazhatnak 1-2\% egyéb alkotóelemet is (Mn, Si, S, P, Cr, Ni, Mo). A martenzites szövetszerkezetü acélok gyártása során az ausztenitési hőmérsékleten való hőn tartást követő gyors (a kritikus hűlési sebességtől nagyobb) hűtéssel érhető el az $\alpha$-martenzit. A fizikai tulajdonságok jelentős része nagyban függ az anyagösszetételtől, valamint a martenzites szövetszerkezet létrehozásához szükséges hőkezelés paramétereitől. Ezek közül elsősorban az acél karbontartalmától és a hűlési paraméterektől függenek a mikroszerkezeti és mechanikai tulajdonságok [1].

A martenzit egyik megjelenési formája a léces martenzit. A tipikus léces martenzit blokkokból áll, ahol a blokkok úgynevezett kötegeket alkotnak [2-4]. A blokkok tovább bonthatók alblokkokra, amelyekben egymással párhuzamos lécek találhatók. Ezek hívjuk martenzitléceknek. 


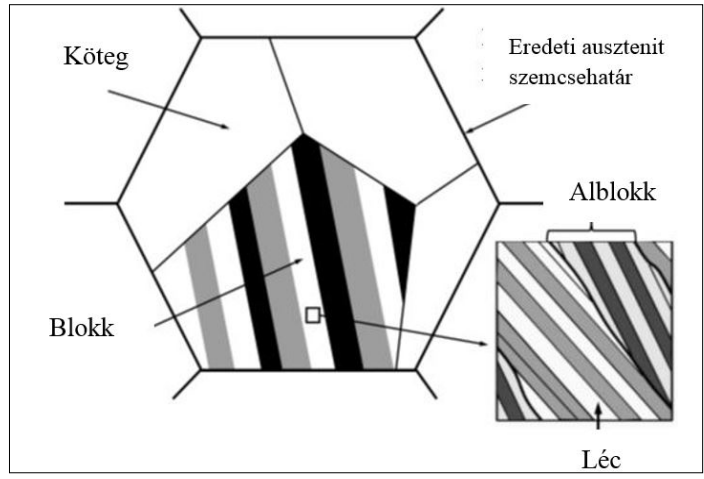

1. ábra. A léces martenzit kötegekböl, blokkokból, alblokkokból és lécekből álló hierarchikus felépitése

Az 1. ábrán láthatjuk a léces martenzit kötegekből, blokkokból, alblokkokból és lécekből álló hierarchikus felépítését.

$\mathrm{Az}$ eredeti ausztenit-szemcsehatárokon belül különböző kristálytani orientációjú pakettek lehetségesek [2-4], ahogyan ezt az 1. ábrán is láthatjuk.

A martenzites szerkezetű acélok, annak ellenére, hogy a képlékenységi tulajdonságaik eléggé limitáltak, mégis mutatnak képlékeny alakváltozást [1, 5-7]. A képlékeny deformációt befolyásoló mechanizmusokat nemrég sikerült feltárni úgynevezett mikrooszlopos és $\mu \mathrm{m}$ nagyságrendű próbatesteken elvégzett szakítóvizsgálatokkal [8-9].

A mikrooszlopos vizsgálatok - attól függően, hogy egy vagy több martenzitblokkot érintettek más és más eredményt mutattak. Azokban a vizsgálatokban, ahol csak egy blokkot vizsgáltak, nem volt a hidegalakításra jellemző keménységnövekedés, és a folyáshatár is nagy (1,2 GPa) volt. Amikor több blokkot egyszerre vizsgáltak, a keménységük nőtt, azonban a folyáshatár hasonlóan nagy értékűnek adódott [8].

Az elvégzett szakítóvizsgálatok esetén, azoknál (próbatestek jeltávja: $100 \mu \mathrm{m}$ ), amelyeknél az aktív csúszósík párhuzamos volt a lécek orientációjával, a kritikus nyírófeszültség 350 MPa volt, míg azokban az esetekben, ahol az aktív csúszósík merőleges volt a lécek orientációjára, a kritikus nyírófeszültség megduplázódott [9].

A két publikációban [8, 9] elvégzett kísérletek alapján a szerzők arra következtettek, hogy a terhelés megoszlik a lécek irányával párhuzamos és merőleges aktív csúszósíkok között. Ahogyan a következő ábrán (2. ábra) is láthatjuk, az alkalmazott feszültség $(\sigma)$ iránya sem egyezik meg az alakváltozásban részt vevő diszlokációk Burgers-vektorainak irányával.

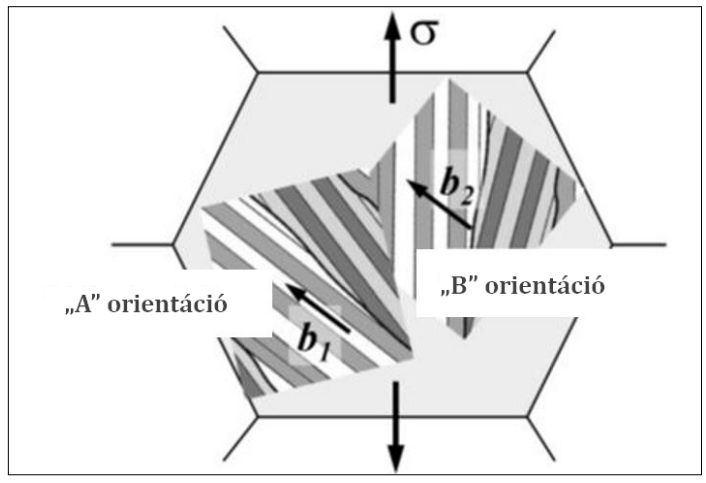

2. ábra. A Burgers-vektorok nem esnek egybe az alkalmazott feszültség irányával

Az eddigieket összefoglalva, egy adott képlékeny deformációra adott válasz attól függ, hogy az aktív Burgers-vektorok (az aktív Burgers-vektor egy adott csúszási rendszer Burgers-vektorai közül az, amelyik részt vesz a képlékeny alakváltozásban) iránya milyen összefüggésben van az alakváltozást okozó feszültség irányával. Végeredményképpen a képlékeny alakváltozás egy olyan szerkezetet hoz létre, amelyben lágy és kemény térfogatelemek (kötegek) jönnek létre. Amennyiben a Burgers-vektorok párhuzamosak a lécek irányával, lágy térfogatelemről (2. ábra „A” orientáció), amennyiben merőlegesek a lécek irányára, kemény térfogatelemről beszélhetünk (2. ábra „B” orientáció).

A rövid bevezetésből is láthatjuk, mennyire fontos, hogy meg tudjuk határozni a képlékeny alakváltozás előtt és után a pakettek orientációját, amelyhez úgynevezett visszaszórtelektron-diffrakciót (EBSD) alkalmazunk. Ennek a vizsgálatnak az elvégzése nagyon gondos minta-előkészítést igényel. A munkánk során ehhez a vizsgálathoz tartozó minta előkészítéséhez dolgoztunk ki egy eljárást.

\section{Anyagok, módszerek, eszközök}

A vizsgálatokhoz a következő táblázatban (1. táblázat) összefoglalt összetételű acélokból készült, $l_{1}=20 \mathrm{~mm}$ és $l_{2}=20 \mathrm{~mm}$ oldalhosszúságú és $h=2,5 \mathrm{~mm}$ vastagságú próbatesteket használtunk. A próbatestek összetételét egy Zeiss Evo MA10-es pásztázó elektronmikroszkóppal (SEM) mértük meg. Ezt követően hőkezeltük a próbatesteket. Először $1100{ }^{\circ} \mathrm{C}$-ra hevítettük őket (ez az acél $\mathrm{A}_{3}$ hőmérséklete felett van), majd 30 percnyi hőntartást követően lehütöttük, hütőközegnek pedig $20^{\circ} \mathrm{C}$-os vizet használtunk. Az edzéssel léces martenzites szerkezetet kaptunk. 
1. táblázat. Az általunk használt próbatestek anyagösszetétele

\begin{tabular}{|c|c|}
\hline Elem & Tömegszázalék \\
\hline Fe & 98,10 \\
\hline C & 0,21 \\
\hline Mn & 1,58 \\
\hline P & 0,03 \\
\hline S & 0,04 \\
\hline Si & 0,04 \\
\hline
\end{tabular}

A következő lépésben a próbatesteket elektromosan vezető melegbeágyazó gyantába ágyaztuk be. Ez azért fontos lépés, mivel mind az EBSD-vel, mind az ionpolírozó berendezéssel csak vezető mintákat lehet jól vizsgálni, így nem kell a gyantából kiszedni a próbatesteket, s ily módon megkockáztatni az esetleges sérüléseket.

A minták előkészítését mechanikai csiszolással és polírozással kezdtük. A csiszoláshoz és a polírozáshoz Jean Wirtz márkájú manuális csiszológépet, valamint különböző szemcseméretű (300 $\mu \mathrm{m}$, $212 \mu \mathrm{m}, 90 \mu \mathrm{m}, 46 \mu \mathrm{m}, 26 \mu \mathrm{m}, 15 \mu \mathrm{m}, 12 \mu \mathrm{m}, 6 \mu \mathrm{m}$ ) SiC-os csiszolópapírt alkalmaztunk, mindegyiket 5 percig. Ezután políroztuk a próbatestek vizsgálandó felszínét. Ehhez kétféle gyémántpasztát (3 $\mu \mathrm{m}, 1 \mu \mathrm{m}$ ) használtunk, 10 percig mindkét fajtát. Eddig a pontig az összes próbatestet ugyanúgy készítettük elő, azonban ez még nem elegendő a visszaszórtelektron-diffrakciós vizsgálatokhoz.

A jobb eredmények elérése érdekében ionsugaras eljárással políroztuk a munkadarabokat Technoorg Linda SEM Prep2 típusú ionsugaras polírozóval. Elsőre könnyünek tűnhet a feladat, de nagyon sok változó (anódfeszültség, anódáram, minta dőlésszöge, idő, ionforrás) pontos beállítása szükséges a megfelelő minta-előkészítéshez. A változók közül a minta dőlésszögét és az ionsugaras polírozás időtartamát változtattuk. A minta dőlésszögét 1-11 között, fokonként változtattuk, az időt pedig 1-6 h között óránként növeltük.

A többi változót a következő értékekre állítottuk be: anódfeszültség: $10 \mathrm{kV}$, anódáram: 3,5 A, ionnyaláb feszültsége: $2 \mathrm{~mA}$, ionnyaláb anyaga: $\mathrm{Ar}^{+}$.

A minták elkészültét követően végeztük el az EBSD-méréseket. A mérésekből úgynevezett képminőségtérképet kaptunk, ezzel az (IQ-) értékkel szokták az EBSD-méréskor kapott kép minőségét meghatározni. Minél nagyobb ez az érték, annál pontosabb és jobb eredményeket kapunk. Célunk, hogy az IQ-érték meghaladja a 40 000-et, mert az e felett kapott eredmények már helyesek.

\section{Eredmények}

Elsőként a minta ideális dőlésszöget állapítottuk meg. Eközben minden egyes mintát 1 órán keresztül ionpolíroztunk. Az egyes dőlésszögekhez tartozó IQ-értékeket a következő diagramon (3. ábra) ábrázoltuk.

A diagramról leolvashatjuk, hogy a legjobb értéket $7^{\circ}$ dőlésszögnél értük el.

Ezt követően csak az ionsugaras polírozás idejét módosítottuk, a dőlésszögét meghagytuk $7^{\circ}$-on. Az eredményeket a 4. ábrán láthatjuk.

A diagramról leolvashatjuk, hogy a legjobb IQ-értéket 4 óráig tartó ionsugaras polírozásnál kaptuk, de a 3 és 5 óra esetén is az átlagos IQ-érték 40000 felett volt. Ezeket számításba véve elmondhatjuk, hogy a legjobb ionpolírozási paraméterek a következők:

- anódfeszültség: $10 \mathrm{kV}$,

- anódáram: 3,5 A,

- ionnyaláb feszültsége: $2 \mathrm{~mA}$,

- ionnyaláb anyaga: $\mathrm{Ar}^{+}$,

- időtartam: $4 \mathrm{~h}$,

- minta dőlésszöge: $7^{\circ}$.

A legjobb paraméterekkel kapott minta IQ-térképét az 5. ábrán mutatjuk.

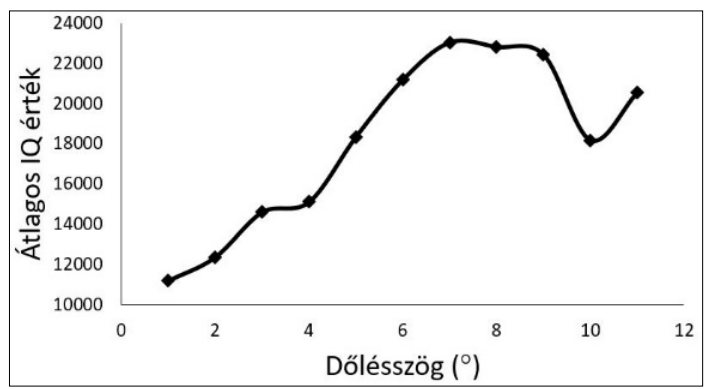

3. ábra. Az általunk használt acél próbatestekröl készült EBSD-mérések átlagos IQ-értékei a minta dőlésszögének függvényében, ahol az ionsugaras polírozás ideje 1 óra volt

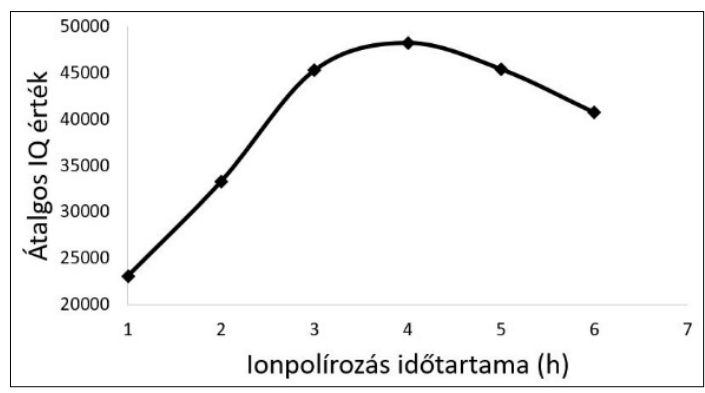

4. ábra. Az általunk használt acél próbatestekről készült EBSD-mérések átlagos IQ-értékei az ionsugaras polírozás idejének függvényében, ahol a minta dőlésszöge $7^{\circ}$ 


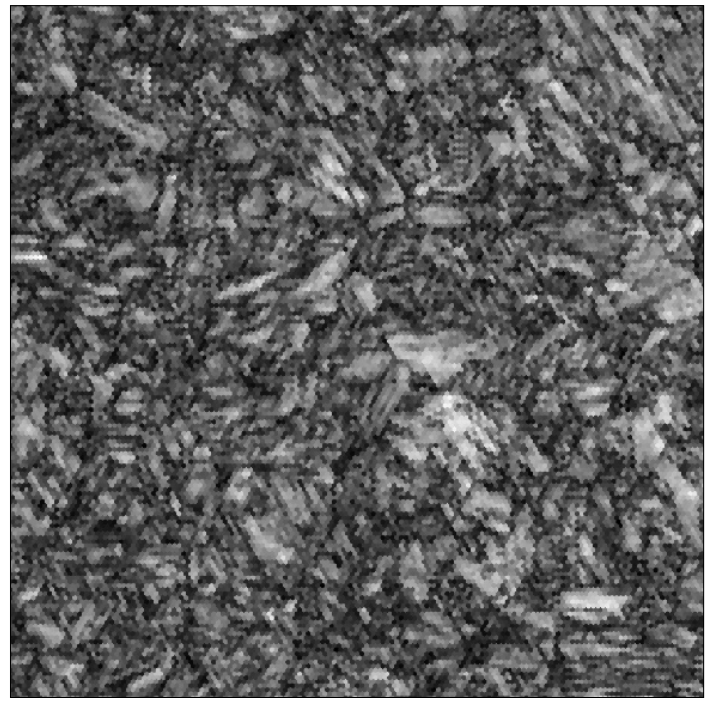

5. ábra. A legjobb, ionsugaras polírozási paraméterekkel kapott IQ-térkép

\section{Köszönetnyilvánítás}

A publikáció az Emberi Erőforrások Minisztériuma NTP-SZKOLL-19-066 kódszámú Nemzeti Tehetség Program pályázatának, valamint a Nemzeti Kutatási, Fejlesztési és Innovációs Hivatal OTKA K124926. számú pályázatának támogatásával valósult meg.

\section{Szakirodalmi hivatkozások}

[1] Krauss G.: Martensite in steel: strength and structure. Material Science and Engineering A, 273275. (1999) 40-57. https://doi.org/10.1016/S0921-5093(99)00288-9

[2] Krauss G., Mader A. R.: The morphology of martensite in iron alloys. Metallurgical Transactions, 2. (1971) 2343-2357.

https://doi.org/10.1007/BF02814873
[3] Morito S., Tanaka H., Konishi R., Furuhara T., Maki T.: The morphology and crystallography of lath martensite in Fe-C alloys. Acta Materialia, 51. (2003) 1789-1799. https://doi.org/10.1016/S1359-6454(02)00577-3

[4] Kitahara H., Ueji R., Tsuji N., Minamino Y.: Crystallographic features of lath martensite in low-carbon steel. Acta Materialia, 54. (2006) 1279-1288. https://doi.org/10.1016/j.actamat.2005.11.001

[5] Swarr T., Krauss G.: The effect of structure on the deformation of as-wuenched and tempered martensire in an Fe-0.2 pct $C$ alloy. Metallurgical Transactions A, 7/1. (1976) 41-48. https://doi.org/10.1007/BF02644037

[6] Michiuchi M., Nambu S., Ishimoto Y., Inoue J., Koseki, T.: Relationship between local deformation behavior and crystallographic features of asquenched lath martensite during uniaxial tensile deformation. Acta Materialia, 57. (2009) 52835291. https://doi.org/10.1016/j.actamat.2009.06.021

[7] Nambu S., Michiuchi M., Ishimoto Y., Asakura K., Inoue J., Koseki T.: Transition in deformation behaviour of martensitic steel during large deformation under unaxial tensile laoading. Scripta Materialia, 60. (2009) 221-224.

https://doi.org/10.1016/j.scriptamat.2008.10.07

[8] Ghassemi-Armaki H., Chen P., Bhat S., Sadagopan S. Kumar S., Bower A.: Microscale-calibrated modeling of the deformation response of low-carbon martensite. Acta Materialia, 61. (2013) 640-3652. https://doi.org/10.1016/j.actamat.2013.10.001

[9] Mine Y., Hirashita K., Takashima H., Matsuda M., Takashima K.: Micro-tension behaviour of lath martensite structures of carbon steel. Material Science and Engineering A, (2013) 535-544. https://doi.org/10.1016/j.msea.2012.09.099 